\title{
THE EFFECTIVENESS OF LOCAL WISDOM-BASED SCIENCE TEACHING MATERIALS IN IMPROVING HIGH SCHOOL STUDENTS CRITICAL THINKING SKILLS
}

\author{
Krisianti Ayu Monita, Erlia Narulita, Aris Singgih Budiarso * \\ Program Studi Pendidikan IPA, Universitas Jember. Jl. Kalimantan 37 Bumi Tegalboto, \\ Krajan Timur, Sumbersari, Jember, 68121. Indonesia, \\ *singgiharis.fkip@unej.ac.id
}

Doi: 10.31943/mangiferaedu.v5i2.99

Received: July 30, 2020 Accepted: November 17, 2020 Published: January 31, 2020

Citation: Monita, K. A., Narulita, E., \& Budiarso, A. S. (2021). The Effectiveness of Local Wisdom-Based Science Teaching Materials in Improving High School

Students Critical Thinking Skills. Jurnal Mangifera Edu, 5(2), 141-149.

\begin{abstract}
In 21 st century learning, critical thinking skills are the main choice that must be mastered by students. This study aims to determine the effectiveness of local wisdom-based science teaching materials in improving junior high school students' critical thinking skills. Most science teachers still apply teacher-centered learning, so students tend to be passive. This type of research is quasi-experimental with a pretest-posttest control group design. The study was conducted in the even semester of the 2019/2020 school year. The subjects of the research were grade VII students. Data collection techniques and instruments in the form of tests that include indicators of critical thinking skills. Data analysis used homogeneity test, Kolmogorov Smirnov normality test, independent sample t-test, and n-gain score. The results of the independent sample $t$-test are sig. $(2$-tailed $)=0,000<$ sig. $\alpha=0.05$. Students' critical thinking skills in the experimental class were higher $(N$-gain score $=39.09 \%)$ than in the control class $(N$-gain score $=12.03 \%)$. Based on the study results, it can be concluded that there is a significant influence on the application of local wisdom-based teaching materials in improving the critical thinking skills of middle school students in the moderate category.
\end{abstract}

Keywords: Critical thinking skills, Local wisdom, Science teaching materials

\section{ABSTRAK}

Pada pembelajaran Abad ke-21, keterampilan berpikir kritis menjadi pilihan utama yang harus dikuasai oleh siswa. Sebagian besar guru IPA masih menerapkan pembelajaran yang berpusat pada guru sehingga siswa cenderung pasif. Penelitian ini bertujuan untuk mengetahui efektivitas bahan ajar IPA berbasis local wisdom dalam meningkatkan keterampilan berpikir kritis siswa SMP. Jenis penelitian yaitu kuasi eksperimen dengan pretest-postest control group design. Penelitian dilaksanakan pada semester genap tahun ajaran 2019/2020. Subjek penelitian yaitu siswa kelas VII. Teknik dan instrumen pengumpulan data berupa tes yang mencakup indikator keterampilan berpikir kritis. Analisis data menggunakan uji homogenitas, uji normalitas kolmagorov smirnov, independent sample t-test, dan n-gain score. Hasil uji independent sample t-test adalah sig. $(2$-tailed $)=0.000<$ sig. $\alpha=0.05$. Peningkatan keterampilan berpikir kritis siswa pada kelas eksperimen lebih tinggi $(\mathrm{N}$-gain score $=39,09 \%)$ dibandingkan dengan kelas kontrol $(\mathrm{N}$ gain score $=12,03 \%)$. Berdasarkan hasil penelitian maka dapat disimpulkan bahwa ada 
Jurnal Mangifera Edu, Volume 5, Issue 2, January 2021, 141-149

pengaruh signifikan pada penerapan bahan ajar berbasis local wisdom dalam meningkatkan keterampilan berpikir kritis siswa SMP dengan kategori sedang.

Kata Kunci: Keterampilan berpikir kritis, Local wisdom, Bahan ajar IPA

\section{PENDAHULUAN}

Perkembangan Ilmu Pengetahuan dan Teknologi (IPTEK) turut menyebabkan pendidikan mengalami perkembangan yang sangat pesat. Secara garis besar, pembelajaran Abad ke-21 memiliki prinsip berpusat pada siswa, kolaboratif, kontekstual, dan terintegrasi dengan masyarakat (Zubaidah, 2016). Menurut Wagner (2010) keterampilan siswa ditekankan pada tujuh keterampilan berikut: (1) kemampuan berpikir kritis dan pemecahan masalah, (2) kolaborasi dan kepemimpinan, (3) ketangkasan dan kemampuan beradaptasi, (4) inisiatif dan berjiwa entrepeneur, (5) mampu berkomunikasi efektif baik secara oral maupun tertulis, (6) mampu mengakses dan menganalisis informasi, dan (7) memiliki rasa ingin tahu dan imajinasi. Pada pembelajaran saat ini, keterampilan berpikir kritis menjadi pilihan utama yang harus dikuasai oleh siswa. Keterampilan berpikir kritis dapat membantu siswa beradaptasi dan mengatasi masalah-masalah yang akan terjadi di lingkungan sekitar mereka (Shanti et al., 2018). Keterampilan berpikir kritis mempunyai peranan penting dalam dunia pendidikan karena siswa akan dilatih untuk mengamati keadaan, memunculkan pertanyaan, merumuskan hipotesis, melakukan observasi dan mengumpulkan data, lalu memberikan kesimpulan. Selain itu, berpikir kritis juga melatih siswa untuk berpikir logis dan tidak menerima sesuatu dengan mudah (Wahyuni, 2015).

Berkembangnya dunia pendidikan tidak membuat keterampilan berpikir kritis di Indonesia memiliki skor yang tinggi di mata dunia. Hal tersebut dibuktikan dengan hasil survey Programme for International Student Assesment (PISA) tahun 2018 terhadap kompetensi sains bahwa tingkat berpikir kritis siswa tergolong rendah dengan perolehan poin dari 403 menjadi 396 poin (OECD, 2019). Berdasarkan hasil studi Trends in International Mathematics and Science Study (TIMSS) 2011 dengan perolehan skor 406 yang menempatkan Indonesia di nomor 40 dari 42 negara peserta TIMSS yang berpartisipasi (Martin et al., 2012). Pencapaian skor prestasi Negara Indonesia pada aspek cognitive domains yang meliputi knowing, applying, dan reasoning. Pada cognitive domains ini mencakup proses kognitif siswa yang terlibat dalam bekerja secara ilmiah dan dalam memecahkan masalah. Hal ini disebabkan karena pembelajaran yang secara langsung menghadapkan siswa pada fenomena alam dalam pembelajaran IPA masih kurang. Selain itu, sebagian besar guru IPA masih menerapkan pembelajaran yang berpusat pada guru 
Jurnal Mangifera Edu, Volume 5, Issue 2, January 2021, 141-149

sehingga siswa kurang memiliki kemampuan dalam berpikir kritis terhadap pembelajaran IPA.

Berdasarkan Permendikbud (2014) pembelajaran IPA memberikan pengalaman langsung kepada siswa sehingga dapat meningkatkan kemampuan untuk menerima, menyimpan, dan mengaplikasikan konsep yang telah dipelajari. Pembelajaran IPA juga diharapkan dapat menjadi wadah perkembangan siswa untuk mempelajari dirinya sendiri dan lingkungan sekitarnya sehingga pembelajaran IPA menjadi lebih bermakna apabila ada kesenimbungan antara materi dengan aktivitas serta lingkungan sekitar siswa. Agar dapat mencapai tujuan pembelajaran tersebut diperlukan komponen pelaksanaan pendidikan yaitu penggunaan bahan ajar.

Bahan ajar yang baik bersumber dari lingkungan sekitar dimana pemilihan isi bahan ajar disesuaikan dengan kebutuhan siswa sehingga bahan ajar yang tepat adalah bahan ajar berbasis local wisdom. Bahan ajar berbasis local wisdom bisa menjadi solusi menarik minat siswa dikarenakan bahan ajar yang sudah terintegrasi dengan local wisdom dapat menciptakan pembelajaran yang kontekstual dan bermakna. Pembelajaran menggunakan lingkungan sebagai sumber dan objek belajar mengarahkan siswa dalam upaya mengaitkan pelajaran akademik pada konteks kehidupan sehari-hari peserta didik. Sesuai dengan pendapat (Safitri et al., 2018) bahwa dalam proses pembelajaran IPA dapat dikembangkan melalui materi IPA yang dikaitkan dengan ciri khas suatu daerah tertentu. Penelitian terkait bahan ajar berbasis local wisdom dilakukan oleh (Fitriani \& Setiawan, 2018) dalam penelitian efektivitas modul IPA berbasis etnosains terhadap peningkatan keterampilan berpikir kritis siswa yang diperoleh hasil bahwa modul tersebut efektif untuk meningkatkan keterampilan berpikir kritis siswa. Penelitian lainnya terkait bahan ajar berbasis local wisdom juga pernah dilakukan oleh (Sari et al., 2018) yang menyatakan bahwa dengan LKS IPA berbasis kearifan lokal kopi pada pokok bahasan usaha dan energi efektif dalam meningkatkan kemampuan berpikir kritis siswa.

Berdasarkan uraian di atas, maka dilakukan penelitian dengan judul Efektivitas Bahan Ajar IPA Berbasis Local Wisdom dalam Meningkatkan Keterampilan Berpikir Kritis Siswa SMP. Tujuan penelitian ini untuk mengetahui efektivitas bahan ajar IPA berbasis local wisdom dalam meningkatkan keterampilan berpikir kritis siswa SMP pada materi interaksi makhluk hidup dengan lingkungannya. 
Jurnal Mangifera Edu, Volume 5, Issue 2, January 2021, 141-149

\section{METODOLOGI PENELITIAN}

Jenis penelitian yang digunakan adalah quasy experiment dengan menggunakan pretest-postest control group design. Penelitian dilakukan dengan cara menerapkan bahan ajar IPA berbasis local wisdom yang telah dikembangkan peneliti lain. Tujuannya untuk mengetahui sejauh mana efektivitas bahan ajar tersebut dalam meningkatkan keterampilan berpikir kritis siswa. Teknik pengumpulan data menggunakan metode tes yang mencakup lima indikator keterampilan berpikir kritis antara lain, memberikan penjelasan sederhana, membangun keterampilan dasar, menyimpulkan, memberikan penjelasan lanjut, serta mengatur strategi dan taktik.

Populasi penelitian ini adalah siswa kelas 7 yaitu kelas 7A, 7B, 7C, 7D yang diasumsikan memiliki kemampuan sama. Penentuan sampel dilakukan dengan mengambil dua kelas secara tidak acak. Sampel penelitian ini adalah siswa kelas 7A (23 siswa) sebagai kelas eksperimen dan siswa kelas 7C (23 siswa) sebagai kelas kontrol.

Analisis data menggunakan uji $n$-gain dan independent sample t-test setelah dilakukan uji normalitas Kolmagorov-Smirnov dengan menggunakan program SPSS v.21. Uji normalitas sebagai uji prasyarat sebelum dilakukan uji parametrik independent sample t-test. Uji independent sample t-test digunakan untuk mengetahui perbandingan ada tidaknya perbedaan efektivitas penggunaan bahan ajar berbasis local wisdom dengan bahan ajar yang biasa digunakan oleh guru dalam meningkatkan keterampilan berpikir kritis siswa pada materi interaksi makhluk hidup dengan lingkungan dengan ketentuan pengujian jika p (2tailed) $>0.05$ maka tidak ada pengaruh yang signifikan sedangkan jika $\mathrm{p}<0.05$ maka ada pengaruh yang signifikan (Riyanto \& Hatmawan, 2020). Peningkatan keterampilan berpikir kritis siswa dapatdiketahui dengan dilakukan uji normalized gain ( $\mathrm{N}$-gain) (Herlanti, 2014), dengan kriteria tinggi jika g>0.70, sedang jika 0,7>g $\geq 0.70$, dan rendah jika $\mathrm{g}<0,30$.

Teknik pengumpulan data pendukung lainnya dengan cara observasi, wawancara, dan dokumentasi. Metode observasi dalam dilakukan untuk mendapatkan data keterlaksanaan pembelajaran menggunakan bahan ajar berbasis local wisdom. Data yang diperoleh dalam teknik wawancara antara lain: bahan ajar yang digunakan guru, kesulitan yang dialami saat proses pembelajaran, keterampilan berpikir kritis siswa, serta tanggapan siswa tentang pembelajaran IPA menggunakan bahan ajar berbasis local wisdom. Sedangkan untuk data dokumentasi yang diambil berupa daftar nama siswa pada kelas yang menjadi subjek penelitian, nilai ulangan harian pada pokok bahasan sebelumnya, data hasil pretest dan postest, foto kegiatan belajar mengajar saat penelitian berlangsung. 
Jurnal Mangifera Edu, Volume 5, Issue 2, January 2021, 141-149

\section{HASIL DAN PEMBAHASAN}

Data yang digunakan untuk mengetahui keterampilan berpikir kritis siswa diperoleh melalui tes uraian berupa pretest dan postest. Berikut merupakan rekapitulasi nilai pretest dan postest siswa SMPN 2 Ajung yang dapat dilihat pada Tabel 1.

Tabel 1. Rekapitulasi Nilai Pretest dan Postest

\begin{tabular}{ccccc}
\hline Komponen & \multicolumn{2}{c}{ Kelas Eksperimen } & \multicolumn{2}{c}{ Kelas Kontrol } \\
& Pretest & Postest & Pretest & Postest \\
\hline Jumlah siswa & 23 & 23 & 23 & 23 \\
Nilai Terendah & 25 & 40 & 25 & 25 \\
Nilai Tertinggi & 70 & 85 & 45 & 60 \\
Rata-rata & 35,65 & 60,43 & 29,34 & 37,60 \\
\hline
\end{tabular}

Hasil pada kelas eksperimen memiliki nilai peningkatan yang lebih baik dibandingkan dengan kelas kontrol. Hal ini terjadi karena pada kelas eksperimen diberikan treatment menggunakan bahan ajar berbasis local wisdom. Perbedaan tersebut dapat diketahui dari hasil rata-rata postest pada kelas eksperimen yang menunjukkan adanya peningkatan.

Untuk mengetahui peningkatan keterampilan berpikir kritis siswa, maka dilakukan uji $\mathrm{N}$-gain yang diintepretasikan ke dalam bentuk $\mathrm{N}$-gain score (\%). Data hasil uji $\mathrm{N}$-gain dapat dilihat pada Tabel 2 .

Tabel 2. Hasil Perhitungan Uji $N$-gain Score (\%)

\begin{tabular}{ccc}
\hline Komponen & Kelas Eksperimen & Kelas Kontrol \\
\hline Jumlah Siswa & 23 & 23 \\
Minimal & 7,69 &, 00 \\
Maksimal & 76,92 & 30,77 \\
Rata-rata & 39,09 & 12,03 \\
\hline
\end{tabular}

Berdasarkan hasil perhitungan uji $\mathrm{N}$-gain score di atas, maka dapat diketahui bahwa rekapitulasi nilai pretest-postest kelas eksperimen (menggunakan bahan ajar berbasis local wisdom) adalah 39,09 atau 39\%, sedangkan kelas kontrol (menggunakan bahan ajar yang biasa digunakan) adalah 12,03 atau 12\%. Hal ini menunjukkan bahan ajar berbasis local wisdom efektif untuk meningkatkan keterampilan berpikir kritis karena terjadi peningkatan nilai siswa setelah menggunakan bahan ajar tersebut. Hal ini dikarenakan adanya peningkatan hasil nilai $N$-gain dari kategori rendah ke kategori sedang. Menurut Wahyuni (2015), perubahan penggunaan bahan ajar dapat melatih siswa dalam meningkatkan keterampilan berpikir kritis. Pengunaan bahan ajar berbasis local wisdom ini membuat pembelajaran lebih bermakna dan kontekstual karena dapat mengarahkan peserta didik pada 
upaya mengaitkan pelajaran akademis dengan konteks kehidupan sehari-hari (Qolbi et al., 2016).

Berdasarkan rekapitulasi $\mathrm{N}$-gain secara keseluruhan, terdapat lima indikator yang digunakan untuk mengetahui keterampilan berpikir kritis siswa pada kelas kontrol dan eksperimen. Data hasil analisis tiap indikator dapat dilihat pada Tabel 3.

Tabel 3. Analisis Tiap Indikator Keterampilan Berpikir Kritis

\begin{tabular}{|c|c|c|c|c|c|c|c|c|c|}
\hline \multirow[t]{2}{*}{ No } & \multirow{2}{*}{$\begin{array}{l}\text { Indikator } \\
\text { Berpikir } \\
\text { Kritis }\end{array}$} & \multicolumn{4}{|c|}{ Kelas Kontrol } & \multicolumn{4}{|c|}{ Kelas Eksperimen } \\
\hline & & $\begin{array}{l}\text { Pre } \\
\text { test }\end{array}$ & $\begin{array}{l}\text { Pos } \\
\text { test }\end{array}$ & $\begin{array}{c}N- \\
\text { gain }\end{array}$ & $\begin{array}{c}\text { Krite } \\
\text { ria }\end{array}$ & $\begin{array}{l}\text { Pre } \\
\text { test }\end{array}$ & $\begin{array}{c}\text { Pos } \\
\text { test }\end{array}$ & $\begin{array}{c}N- \\
\text { gain }\end{array}$ & $\begin{array}{c}\text { Krite } \\
\text { ria }\end{array}$ \\
\hline 1. & $\begin{array}{l}\text { Memberikan } \\
\text { penjelasan } \\
\text { sederhana }\end{array}$ & 115 & 130 & 0,04 & Rendah & 145 & 315 & 0,53 & Sedang \\
\hline 2. & $\begin{array}{l}\text { Membangun } \\
\text { keterampilan } \\
\text { dasar }\end{array}$ & 140 & 210 & 0,21 & Rendah & 235 & 330 & 0,42 & Sedang \\
\hline 3. & Menyimpulkan & 145 & 190 & 0,14 & Rendah & 130 & 325 & 0,59 & Sedang \\
\hline 4. & $\begin{array}{l}\text { Membuat } \\
\text { penjelasan } \\
\text { lebih lanjut }\end{array}$ & 130 & 235 & 0,31 & Sedang & 160 & 245 & 0,28 & Rendah \\
\hline 5. & $\begin{array}{l}\text { Mengatur } \\
\text { strategi dan } \\
\text { taktik }\end{array}$ & 115 & 115 & 0 & Rendah & 115 & 200 & 0,25 & Rendah \\
\hline
\end{tabular}

Berdasarkan hasil analisis tiap indikator keterampilan berpikir kritis, maka dapat diketahui bahwa pada kelas kontrol indikator memberikan penjelasan sederhana hasil $\mathrm{N}$-gain sebesar 0,04 dikategorikan rendah. Hal serupa juga terjadi pada indikator membangun keterampilan dasar, hasil $N$-gain menunjukkan hasil sebesar 0,21 yang dikategorikan rendah. Pada indikator kesimpulan, hasil $\mathrm{N}$-gain sebesar 0,14 yang dapat dikategorikan rendah. Pada indikator membuat penjelasan lebih lanjut, hasil $\mathrm{N}$-gain sebesar 0,31 yang dapat dikategorikan sedang. Pada indikator mengatur strategi dan taktik, hasil $\mathrm{N}$-Gain tidak mengalami peningkatan dan diperoleh hasil $\mathrm{N}$-gain sebesar 0 yang dikategorikan rendah. Sedangkan untuk lima indikator berpikir kritis pada kelas eksperimen secara rinci menunjukkan bahwa pada indikator memberikan penjelasan sederhana hasil $\mathrm{N}$-gain sebesar 0,53 dikategorikan sedang. Pada indikator membangun keterampilan dasar, hasil $\mathrm{N}$-gain menunjukkan hasil sebesar 0,42 yang dikategorikan sedang. Pada indikator kesimpulan, hasil $N$-gain sebesar 0,59 yang dapat dikategorikan sedang. Pada indikator membuat penjelasan lebih lanjut, hasil $\mathrm{N}$-gain sebesar 0,28 yang dapat dikategorikan rendah. Pada indikator mengatur strategi dan taktik, hasil $\mathrm{N}$-gain sebesar 0,25 yang dikategorikan rendah.

Berdasarkan hasil tersebut menunjukkan peningkatan keterampilan berpikir kritis kelas eksperimen selalu lebih tinggi dibandingkan kelas kontrol. Peningkatan ini 
memberikan informasi bahwa penggunaan bahan ajar berbasis local wisdom dapat meningkatkan keterampilan berpikir kritis dibandingkan dengan bahan ajar yang biasa digunakan di sekolah. Indikator keterampilan berpikir kritis yang paling menonjol peningkatannya yaitu menyimpulkan dengan kategori sedang. Hal ini dikarenakan pada bahan ajar berbasis local wisdom terdapat beberapa komponen bahan ajar yang meliputi teks dan gambar terkait kegiatan untuk melatih keterampilan berpikir kritis siswa. Ciri khas bahan ajar ini adalah berbasis pendekatan kontekstual dimana mengaitkan materi interaksi makhluk hidup dengan lingkungan tempat tinggal siswa yaitu daerah perkebunan kopi. Bahan ajar berbasis local wisdom yang digunakan berisi materi-materi tentang konsep lingkungan, komponen-komponen di dalam lingkungan, pengertian interaksi, interaksi dalam ekosistem membentuk suatu pola, serta interaksi manusia memengaruhi ekosistem. Selain itu, terdapat pertanyaan-pertanyaan untuk diskusi yang dikerjakan oleh siswa untuk mengarahkan mereka menemukan konsep penting terkait materi ajar (Wahyuni, 2015). Sedangkan untuk indikator memberikan penjelasan lebih lanjut dan mengatur strategi taktik memiliki kriteria rendah. Hal ini dikarenakan siswa mampu memahami maksud dari permasalahan tetapi belum mampu menuliskan hubungan-hubungan konsep yang digunakan dalam permasalahan untuk memilih strategi dan taktik dengan tepat. Hal ini sejalan dengan penelitian yang dilakukan oleh Prihartiningsih et al., (2016), dan Normaya (2015) yang menyatakan bahwa kemampuan berpikir kritis siswa SMP masih belum berkembang atau masih rendah. Rendahnya kemampuan berpikir kritis siswa dikarenakan pembelajaran yang diterapkan di sekolah masih berpusat pada guru sehingga kemampuan berpikir kritis siswa tidak berkembang. Menurut Patonah (2014) proses pembelajaran IPA masih didominasi oleh guru, pembelajaran cenderung menghapal sehingga siswa sulit menyampaikan gagasannya sendiri, lemah dalam menganalisis, bergantung pada orang lain dibandingkan bertanggung jawab terhadap pilihannya sendiri.

Perbandingan ada tidaknya perbedaan efektivitas penggunaan bahan ajar berbasis local wisdom dengan bahan ajar yang biasa digunakan oleh guru dalam meningkatkan keterampilan berpikir kritis siswa pada materi interaksi makhluk hidup dengan lingkungan dapat diketahui dengan menggunakan uji Independent Sample T-Test. Data hasil uji Independent Sample T-Test dapat dilihat pada Tabel 4. 
Jurnal Mangifera Edu, Volume 5, Issue 2, January 2021, 141-149

Tabel 4. Hasil Uji Independent Sample T-Test

\begin{tabular}{ccccccc}
\hline & \multicolumn{5}{c}{$\begin{array}{c}\text { Levene's Test } \\
\text { for Equality of } \\
\text { Variance }\end{array}$} & t-test for Equality of Means \\
& $\boldsymbol{F}$ & Sig. & $\boldsymbol{T}$ & $\boldsymbol{D f}$ & Sig.(2-tailed) \\
\hline $\begin{array}{c}\text { Hasil } \\
\text { Keterampilan } \\
\text { Berpikir } \\
\text { Kritis }\end{array}$ & $\begin{array}{c}\text { Equal variances } \\
\text { assumed } \\
\text { Equal variance } \\
\text { not assumed }\end{array}$ &, 691 &, 410 & 6,952 & 44 &, 000 \\
\hline
\end{tabular}

Berdasarkan hasil uji Independent Sample T-Test diperoleh hasil besar nilai signifikansi (Sig.) pada tabel Levene's Test for Equality of Variance sebesar 0,410. Hal ini menunjukkan bahwa data untuk kelas eksperimen dan kelas kontrol berasal dari data yang homogen. Sedangkan untuk nilai Sig.(2-tailed) diperoleh 0,000<0,05 maka $\mathrm{H}_{0}$ ditolak dan $\mathrm{H}_{\mathrm{a}}$ diterima, artinya ada pengaruh signifikan pada penerapan bahan ajar IPA berbasis local wisdom untuk meningkatkan keterampilan berpikir kritis siswa SMP.

\section{SIMPULAN}

Bahan ajar berbasis local wisdom dapat meningkatkan keterampilan berpikir kritis siswa SMP. Hal ini dapat dilihat dari hasil uji Independent Sample T-Test diperoleh hasil bahwa terdapat pengaruh signifikan pada penerapan bahan ajar IPA berbasis local wisdom untuk meningkatkan keterampilan berpikir kritis siswa SMP. Analisis dengan menggunakan uji $\mathrm{N}$-gain score menunjukkan bahwa peningkatan keterampilan berpikir kritis pada kelas eksperimen termasuk pada kategoi sedang dan pada kelas kontrol dikategorikan rendah.

Saran untuk penelitian selanjutnya diharapkan dapat mengembangkan dan menerapkan pembelajaran menggunakan bahan ajar berbasis local wisdom pada pokok bahasan yang berbeda dan untuk soal tes keterampilan berpikir kritis lebih mengarah ke critical thinking siswa.

\section{DAFTAR PUSTAKA}

Fitriani, N. I., \& Setiawan, B. (2018). Efektivitas Modul IPA berbasis Etnosains terhadap Peningkatan Keterampilan Berpikir Kritis Siswa. Jurnal Penelitian Pendidikan IPA, 2(2), 71-76.

Herlanti, Y. 2014. Tanya Jawab Seputar Penelitian Pendidikan Sains. Jakarta: Universitas Syarif Hidayatulah. ISBN 978-602017290-3-8.

Martin, M. O., Mullis, I. V. S., Foy, P., \& Stanco, G. M. (2012). TIMSS 2011 International Results in Science. ERIC. 
Jurnal Mangifera Edu, Volume 5, Issue 2, January 2021, 141-149

Normaya, K. (2015). Kemampuan Berpikir Kritis Siswa dalam Pembelajaran Matematika dengan Menggunakan Model Jucama di Sekolah Menengah Pertama. EDU-MAT Jurnal Pendidikan Matematika, 3(1), 92-104.

OECD. 2019. Country Note - Programme For International Student Assesment (PISA) Results From PISA 2018. Indonesia: OECD Publishing.

Patonah, S. (2014). Elemen Bernalar Tujuan pada Pembelajaran IPA melalui Pendekatan Metakognitif Siswa SMP. Jurnal Pendidikan IPA Indonesia, 3(2).

Permendikbud. 2014. Kurikulum 2013 Sekolah Menengah Pertama/Madrasah Tsanawiyah. Jakarta: Kementerian Pendidikan dan Kebudayaan.

Prihartiningsih., Zubaidah, S., dan Kusairi. 2016. Kemampuan Berpikir Kritis Siswa SMP pada Materi Klasifikasi Makhluk Hidup. Prosiding Seminar Nasional Pendidikan IPA Pascasarjana UM. (1) : 1053-1062.

Qolbi, F., Kartimi, K., \& Roviati, E. (2016). Penerapan Pembelajaran Berbasis Sains Budaya Lokal Ngarot untuk Meningkatkan Keterampilan Berpikir Kritis Siswa Pada Konsep Plantae (Studi Eksperimen Kelas X di SMA N 1 Lohbener). Scientiae Educatia: Jurnal Pendidikan Sains, 5(2), 105-121.

Riyanto, S., \& Hatmawan, A. A. (2020). Metode Riset Penelitian Kuantitatif Penelitian di Bidang Manajemen, Teknik, Pendidikan Dan Eksperimen. Deepublish.

Safitri, A. N., Subiki, S., \& Wahyuni, S. (2018). Pengembangan Modul IPA berbasis Kearifan lokal Kopi pada Pokok Bahasan Usaha dan Energi di SMP. Jurnal Pembelajaran Fisika, 7(1), 22-29.

Sari, R., Harijanto, A., \& Wahyuni, S. (2018). Pengembangan LKS IPA Berbasis Kearifan Lokal Kopi pada Pokok Bahasan Usaha dan Energi di SMP. Jurnal Pembelajaran Fisika, 7(1), 70-77.

Shanti, W. N., Sholihah, D. A., \& Abdullah, A. A. (2018). Meningkatkan Kemampuan Berpikir Kritis melalui CTL. Jurnal Pembelajaran Matematika, 5(1).

Wagner, T. (2010). Overcoming the Global Achievement Gap (online). Cambridge, Mass., Harvard University.

Wahyuni, S. (2015). Pengembangan Bahan Ajar IPA untuk Meningkatkan Kemampuan Berpikir Kritis Siswa SMP. PROSIDING: Seminar Nasional Fisika Dan Pendidikan Fisika, 6(6).

Zubaidah, S. (2016). Keterampilan Abad ke-21: Keterampilan yang Diajarkan melalui Pembelajaran. Seminar Nasional Pendidikan, 2(2), 1-17. 